\title{
Civilisations
}

Revue internationale d'anthropologie et de sciences

humaines

39 | 1991

Japon : les enjeux du futur

\section{Toshiba in the U.K.}

\section{Malcolm Trevor}

URL : https://journals.openedition.org/civilisations/1656

DOI : $10.4000 /$ civilisations. 1656

ISSN : 2032-0442

\section{Éditeur}

Institut de sociologie de l'Université Libre de Bruxelles

\section{Édition imprimée}

Date de publication : 30 octobre 1991

Pagination : 161-190

ISBN : 2-87263-044-9

ISSN : 0009-8140

\section{Référence électronique}

Malcolm Trevor, «Toshiba in the U.K. », Civilisations [En ligne], 39 | 1991, mis en ligne le 06 juillet 2009, consulté le 21 septembre 2021. URL : http://journals.openedition.org/civilisations/1656 ; DOI : https:// doi.org/10.4000/civilisations. 1656 
TOSHIBA IN THE U.K.

Malcolm TREVOR

The background

Toshiba set up its first British operation in 1973. This was a sales and distribution company which, under the regulations in force at the time, was allocated a quota to sell 20,000 imported Japanese TV sets a year in the British market.

In order to expand its market share and the scope of its British operations, the company then entered into a joint venture in November 1978 with the Rank Organisation to produce television sets at Rank's existing facilities in the West of England, with assembly centred on the factory at Plymouth. Toshiba invested $£ 3$ million and a production target of 350,000 sets a year was set.

In fact the nearest to the target that the joint venture was able to get was 270,000 sets a year. Toshiba's shareholding was no more than 30 per cent but it was said to have a degree of influence over company organisation and management - and it also appointed the chairman. However, the failure to reach the production target was disappointing and the joint venture was losing money. It was therefore agreed by mutual consent to dissolve it and what had been Rank's entire television and TV sub-assembly production at four factories in Devon and Cornwall was completely closed down in March 1981.

The entire workforce was discharged. Rank had to write off $£ 18.8$ million and bear 70 per cent of the joint venture's losses. In the local economy, which was already suffering from recession and in which there were hardly any other employment 
opportunities, the closure produced widespread gloom - but also acted as a stimulus, as the crisis impelled local politicians and trade union leaders to try and persuade Toshiba to take over the venture on a wholly-owned basis. The company was assured of a friendly welcome.

The reasons for the failure of the joint venture have been variously discusses and it is not without interest that another joint venture in the same industry, GEC-Hitachi, which had started just before Rank-Toshiba, also encountered problems and eventually sought the same type of solution : in this case a takeover by Hitachi in 1984. But in spite of the apparent similarities, the cases of the two companies were not identical, though in both instances it would probably be fair to say that neither joint venture succeeded in making the best use of the Japanese partner's engineering and organisational expertise.

At first it was not certain whether Toshiba would be interested in taking over from Rank and there was very careful scrutiny of the local situation and then of the figures in the business plan before the company's Board in Japan decided to go ahead. There was a determination on all sides that everything had to be done to turn what had been the previous failure into success. The Financial Times, for instance, saw it as a case of Toshiba 'taking on a salvage mission' out of the 'wreckage' of the old company and this was scarcely an exageration. The Plymouth factory had originally opened in 1948 and the crisis meant that the point had been reached where major changes, and not just ad hoc attempts to patch up the system, were needed ${ }^{1}$.

\section{Starting the new company}

People who had seen the success of other Japanese manufacturing operations in Britain thought that Toshiba, in sole control of a wholly-owned operation, would be free to 
innovate, organise and manage according to its own ideas and that it would be similarly successful. After the traumatic experience of the closure of the old company, the local staff were likewise convinced that the time for change had come.

It needs to be emphasised how thoroughgoing this change was. The first thing was the change in the structure of the operation itself, which was expressed in Figure 1 below following the diagram prepared by the company for public presentations.

Figure 1. Organisational change : Rank-Toshiba joint venture to Toshiba Consumer Products (UK) Ltd.

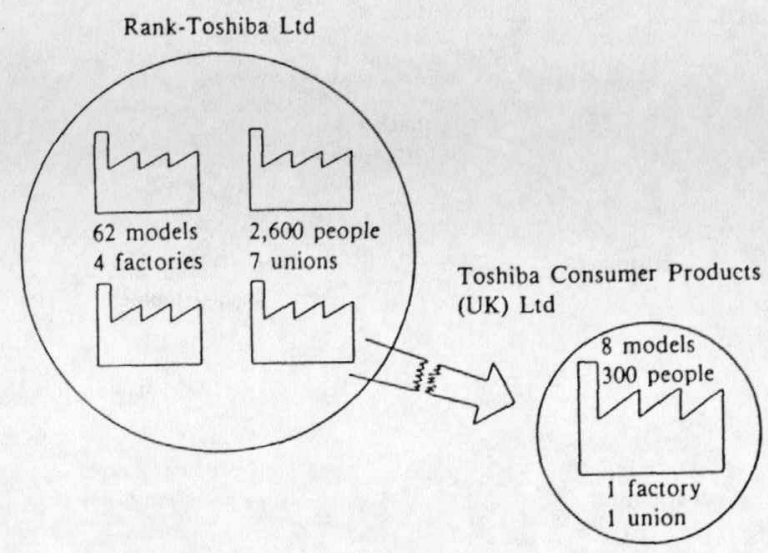

Source: TCP. 
The second thing was the new integrated concept underlying the marketing and production system - which might be compared with that of the traditional type of bespoke tailor, who only makes a suit when the customer has ordered it. In the days of the old company, coordination between sales and production seemed to have been poor and there were stories of quantities of unsold sets piling up in the warehouse; with all the cost and waste that this implies. Under the new system, sets are only produced at Plymouth when the sales company has already received an order. The Managing Director of the manufacturing company at Plymouth sits on the Board of the marketing company near London and there is continual close liaison between the two. The aim is the type of integrated marketing and production system found at Toshiba and other companies in Japan, which can also be characterised as a 'logistic chain' as in Figure 2 below.

Figure 2. Integrated marketing and production system, or 'logistic chain'

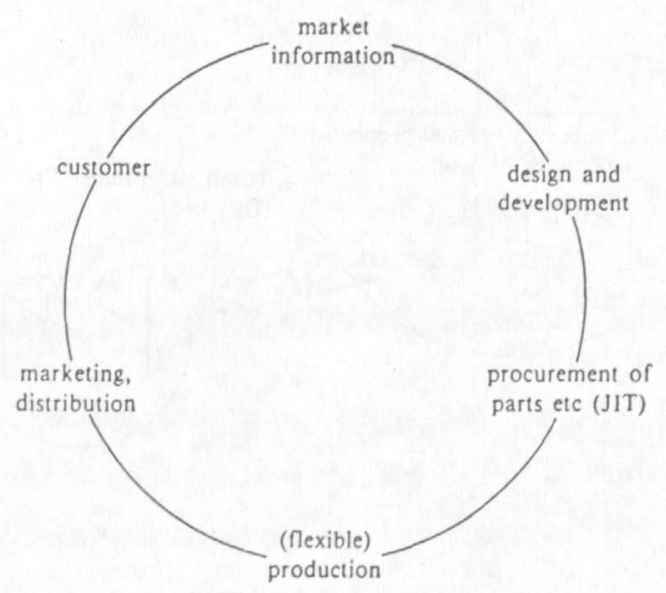


What can not be represented in the diagram is the dynamic character of the new system, which now typifies the automobile industry and many others in Japan. Marketing people, for example, constantly feed information to design and development, who in turn work closely with production engineering people to ensure that good sales ideas do not become production disasters. In British companies there have been too many instances of production managers who have not been involved at all at the design and development stage simply being told to put new products into production that, however briliant as sales ideas, create severe production difficulties. The idea of the continuous 'logistic chain' is not merely to avoid such problems but, more positively, to promote continual product development and to bring new products on to the market ahead of competitors ${ }^{2}$.

As far as the Plymouth factory was concerned, one of the biggest changes on the production side, which had major organisational implications, as the change from Rank's policy of making so many of the sub-assemblies and parts itself at its various factories in Devon and Cornwall, to Toshiba's policy of concentrating on the production of the final product. This was a policy that closely reflected the situation in Japan, where manufacturers like Toshiba can rely on outside suppliers to deliver good quality parts on time $e^{3}$. The aim at Plymouth was to achieve "a high standard from day one" and to run "a clockwork factory, with no surprises good or bad". But the most important means of doing this was through organisation : not through technology. From the point of view of technology, the difference between the new company and the old was not so much one of technology per se as one of a rearranged and more logical layout, with different working practices, consistent with the concentration of manufacturing at the one site at Plymouth, in contrast to the previous attempt to do everything in-house. This is an important point for those who mistakenly believe that Japanese successes in manufacturing automatically grow out of 
the latest technology. Factory visits in Japan show that not all the equipment in use is by any means the latest but that what makes the difference is the determination to use it to the best advantage; in other words, management.

\section{The new management approach}

It was decided that all those who had worked in the old company would be eligible to apply for jobs in the new one and nine hundred people applied for the three hundred jobs that were available. Of those taken on, all except one had worked in the old company. They went through an extremely careful selection and screening process, during which they were shown a videotape made by the new Managing Director, Geoffrey Deith, explaining what sort of company Toshiba was and what would be expected. The tape emphasised points such as punctuality, attendance, quality and flexibility : all points that are of great importance in Japan but which can not simply be said to be 'Japanese'. Here it needs to be borne in mind that the Plymouth company has now added a new division and a new factory producing microwave ovens, and that it now employs nearly 1,200 people; so that those who remain of the original three hundred who started work at the reorganised factory in May 1981 are outnumbered by those, many of them young, who have since joined the company.

It is sometimes supposed by people without any first hand experience of the company at Plymouth that because Toshiba is Japanese-owned, therefore its new approach must be 'Japanese' but this is an over-simplification. Japanese firms operating in Europe, like European firms operating in Japan, know that they must to some extent modify their approach in order not to conflict with the local environment. Depending on factors such as the product market, the type of workforce, local employment and industrial relations legislation etc, managers 
must decide at what point along the continuum running from 'Japanese' to 'European' they are going to make their compromise. Their decision is crucial because if they get it wrong the company will be likely to face problems that will reduce its operating efficiency. Many Japanese managers worry that if they make too many compromises the company will lose its competitive edge. Others, on the other hand, hesitate to introduce 'Japanese' practices because of, sometimes exaggerated, fears that they will not be acceptable locally due to the local 'culture'; although it has to be said that many Japanese companies do not prepare their managers very thoroughly for overseas assignments, so that they may have rather stereotyped ideas of the local society. While it can not be claimed that there is some simple formula, like the recipe for a cake, that can be applied to the management of Japanese companies in Europe, there are companies that have been successful in aiming for a blend of those home country and host country practices that together produce the most competitive result in the local setting.

As far as Toshiba at Plymouth was concerned, there was a definite meeting of minds and a high degree of trust between the top British and Japanese management, without which even the design, not to mention the implementation, of the new approach would have been difficult. Before the start up of the new company there were exhaustive and free-ranging discussions of how the new approach 'from day one' should operate, bearing in mind the initial target of producing 100,000 TV sets a year with 300 people. Those taking part in the discussions comprised the new management team of Geoffrey Deith, the Managing Director, Mr. K. Komada, the senior Japanese engineering manager, since promoted to take charge of the TV Division at the parent plant in Japan, and five senior British managers. The meeting of minds came about because the local management, particularly after the crisis with the joint 
venture, and the Japanese management were converging from different starting points on similar solutions.

Geoffrey Deith especially, who played a key role in formulating the new approach, persuading the Board in Japan that it was workable and implementing it once it had been agreed, had many years previously become interested in new approaches to management. This was through his acquaintance with the case of the Glacier Metal Company, whose innovations in the Britain of the late 1940s had made it a seminal object of study ${ }^{4}$. Glacier was famous for its system of representatives elected from all levels of the organisation and from all departments, together forming an advisory council, and at an audio company where he had previously been. Managing Director Deith had tried out a similar participatory system for a considerable number of years. He therefore knew the possibilities and problems from experience and with the closure of the joint venture and the takeover by Toshiba he saw the chance of putting forward his ideas to a receptive Japanese management and took the opportunity with enthusiasm. Like the Japanese, he believed in 'working together with a common purpose', though, like the Japanese again, on a practical and not on an overly idealised basis. By training, he was himself an engineer and familiar with the realities of production management.

The new approach was a conscious attempt to implement an integrated management system, made up of different elements. These elements can be identified separately for purposes of analysis but the system can only work as intended when they fit together, like the meshing of gear wheels. The elements of the structure of the organisation and of the integration of marketing and production have been briefly outlined above. To these were added the personnel management and employee relations systems, including the representative system. Seen as a whole, this integrated 
approach amounted to a 'package', in which the various elements were consciously intended to be consistent with one another and to be mutually reinforcing. Indeed the management team discussions about the design of the systems was itself an integral part of the approach : in contrast to companies where new systems would have been simply imposed from above without discussion. It as perhaps inevitable that the news media, with their need to find the most newsworthy 'story', should have taken some elements out of context but company managers themselves know that the success of the new approach depends on its being properly integrated. The point was appreciated by Roy Sanderson, National Officer of the Electrical, Electronic, Telecommunication and Plumbing Union (EETPU), who had been involved at an early stage in negotiations concerning the new approach. It was his view that, 'You can't have bits of it, like reduced manning. It hangs together as a package'

In a presentation that he gave to a London audience, $\mathrm{Mr}$. Komada emphasised that whether an applicant was selected or not very much depended on whether he or she was likely to be a good team member, as well as competent at the job. In fact two of the four 'key principles' guiding the start up of the new company were directly concerned with personnel. The four 'key principles' ${ }^{\prime 6}$ were :

1. To establish a high standard from day one.

2. To recruit the right people.

3. To develop employee attitudes.

4. To develop suppliers' attitudes.

To symbolise the break with the unsuccessful past that was being made, change was made explicit not only by means of the company recruitment video but also in such external details as the appearance of the plant itself. As one manager put it, 'We even painted the floor'. 
Personnel management and employee relations

From the beginning, the new company has had a Managing Director and a Personnel Director who are both British. Indeed, with the exception of Japanese managers in liaison and technical advisory positions, including the purchasing of components from Japan etc, management has been a local responsibility. The number of expatriates has been greatly reduced since the time of the start up when, following normal practice, a team of Japanese technical advisors was brought over to help with training and with setting up the operation.

Consistent with the aim 'to develop positive employee attitudes', mentioned as the second of the four 'key principles' guiding the start up above, the actions listed in Table 1 below were put into effect.

Table 1. Actions to develop positive employee attitudes

a. Careful selection and induction

b. Autonomy of local management

c. Open style management and consultation

d. Five-minute morning meetings. Monthly meetings. Six-monthly business reviews (for all personnel)

e. Few levels of management

f. Open plan offices

g. Development of team approach

h. All on monthly staff with common terms and conditions

i. Single status restaurant

j. Wearing of (company) coats

k. Grade promotional opportunities

1. Total flexibility

$\mathrm{m}$. Attendance and timekeeping disciplines

n. No smoking or food in production areas 


\section{o. Individual responsibility for (work) space cleaning \\ p. Small circle activities \\ q. Annual formal performance reviews}

\section{(Source : TCP)}

The 'common terms and conditions' of employment referred to in Item $\mathrm{h}$ above are often popularly referred to as 'single status', and although the expression is not strictly speaking correct, it sums up much of the reality of the new approach. Whereas in the old days, and still in many other 'traditional' firms, there had been hourly paid and monthly paid employees, blue collar workers and white collar staff, and separate restaurants for managers, supervisors and employees, with other overt status differences such as reserved parking spaces for 'managers' cars, these distinctions now no longer exist. All personnel are plaid in the same way at the same intervals. All eat in the same restaurant, which has been designed to meet the same standards as good motoray cafeterias. All wear the same 'company coat'; in other words the same type of blue jacket with a small company logo sewn on in red. They wear a name badge, with the name by which they as individuals choose to be known, but without specifying their department, as it was felt that this would be inconsistent with the team approach and reminscent of departmentalism. All share the same holiday entitlement. The first person to arrive in the car park gets the best place. There is one large open plan office for the administration in which everyone, including the Managing Director, works side by side. The only difference in conditions is naturally the amount of salary.

For managers in particular it was made clear that what was aimed at was a 'total team' and that 'if one department fails, the total company fails'. In other words, there was to be no room for functional barriers, empire building or the 'that's 
not my job' mentality. The present Personnel Director, for example has a training background and does not see himself as split off into an isolated or 'separate' function, as some qualified 'professionals' tend to do.

There are four grades of ordinary employee. Among the company's 'Major objectives and principles' is 'to reward individual employees on the basis of proficiency over a range of job skills and the flexibility of their contribution to the company'. Flexibility is not merely expressed as a desirable goal but is built into the reward system. Eighteen production skills are recognised and increments for skills are paid. A formal assessment of the individual employee is carried out annually, in accordance with Item $2 \mathrm{c}$ in Table 2 below. All skills in the company are classified under either administration, production or key operations and are clearly defined : an echo of the high degree of definition at the Glacier Metal Company rather than of standard Japanese practice where flexibility and the absence of functional barriers are assumed. But operators are themselves responsible for their own quality control and the old Tayloristic division between specialist quality inspectors, or 'brain workers', and ordinary line operators without any responsibility for the quality of their work, or 'manual workers', no longer exists.

Discipline on the shop floor includes the prohibition of eating, drinking or smoking in production areas but, as in factories in Japan, areas for employees on the different lines are provided at the side of the line, with chairs and tables, where they can drink tea and relax during the breaks. This type of discipline is sometimes characterised as 'Japanese', or even allegedly typical of the 'disciplined' Japanese nation, but the fact is that it is the same discipline that was found in british radio factories in the 1930s. In this instance, as in some others, Japanese influence has led to the reintroduction of practices that were formerly standard and which can be said to constitute 
sound management, rather than to any particular innovation; let alone anything 'exotic'.

The task orientation of the personnel and production systems needs to be remembered when considering the participatory and industrial relations aspects of the overall management system. At the same time the Toshiba management deserves the credit for having the vision and confidence to accept the new approach, which many British managements would probably not have done. Des Thomson, the Managing Director after Geoffrey Deith, for example, spoke of the need to 'break down traditional attitudes' and to create a new style of relations at work. The management team discussed every item of policy in detail before proposing its adoption and Deith himself presented a selection of company coats, or uniform jackets, before a decision on its colour and style was reached. Des Thomson saw the wearing of the jacket as 'very fundamental - it would define us as different' : different, that is to say, from 'traditional' companies witheir status distinctions and the tendency for the management to be remote from the shopfloor. But not 'different' in the sense of being eccentric or out of touch with the social environment in which the company operates. The latter point was made explicit in the statement of business objectives reproduced in Table 2 below.

Table 2. Toshiba Consumer Products (UK) Ltd. Business objectives

1. To provide products for Toshiba European sales companies and independent dealers :
a. Of the right type
b. At the right time
c. At the right cost
d. At a high level of quality and reliability 
2. To develop within TCP an industrial culture in which all members of the company :
a. Willingly maximise their personal contri- bution
b. Can identify with the objectives of the Company
c. Can develop and grow in personal terms
d. Feel a joint loyalty to Toshiba as their parent company and to TCP as a UK operation

3. To work in harmony with the Trade Union

4. To work closely with all suppliers in order to :
a. Minimise product cost
b. Maximise product quality
c. Minimise inventory holding

5. To maintain within Plymouth a high reputation for Toshiba as an employer and as a Company which supports the community in which it operates

\section{In Summary}

To generate the highest levels of profit in a consistent manner, without deviating from the high principles of Toshiba.

\section{(Source : TCP)}

Even under the joint venture there had been seven union bargaining units, representing six unions, although the EETPU had the largest membership in the factory. Almost all Japanese manufacturing operations in Britain have a union agreement and there was never the idea of managing the company on a non-union basis, as one or two other Japanese manufacturers in the electronics industry are doing. The EETPU was involved in discussions from an early stage but while the management were prepared to recognise one union for bargaining purposes they certainly did not want to encumber themselves with the old type 
of multi-union bargaining. In this respect, the closure of the old company provided a good opportunity for putting union relations on a better footing.

In fact, Toshiba became famous for signing the first of what are popularly, if not quite accurately, known as 'single-union, no-strike' deals : a type of agreement that has been spreading in the UK and which some commentators see as characteristic of the 'new industrial relations' in the country which have arisen since the defeat of the Labour Party and its excessively unionfriendly policies ${ }^{7}$. The exact details of the agreements vary in each case but another prominent example has been that of Nissan, which also enjoyed the advantage of starting out on a new 'green field' site. But Hitachi, which was unable to close down completely and start afresh when it moved from joint venture to wholly-owned status, has shown that it is possible to change to a single-union agreement without the advantage of a 'green field' site; even though it is of course more difficult.

Under the agreement at Plymouth, the EETPU, which had 80 per cent of the union membership at the time of the joint venture, was formally recognised as the sole bargaining partner; although employees are free to belong to another union or to no union at all if they wish. Because of the recession and a certain amount of disillusion with unions and their effectiveness in providing practical benefits to their members, union membership in the UK has been declining and there is keen competition among unions for members. There is also a trend towards mergers, in order to create unions with numerical strength : something that the EETPU itself may be involved in. These reasons make 'single-union' bargaining agreements attractive to unions; while for management it also becomes easier to get agreement on flexible working practices. This is essential in industries such as electronics where fast response to changes in markets, technologies and products is crucial for survival. On its side, the EETPU has made a 
speciality of offering flexibility as a strong 'selling point' to newly established companies in this type of industry and has also canvassed Japanese companies by holding presentations detailing what it is prepared to offer at sessions in Japan.

In October 1986, just five and a half years after the start up of the new company, a celebration was held to mark the production of Toshiba's millionth British-made TV set. The programme for the ceremony contained a message from the Managing Director, Des Thomson, stating that :

Annual television production has increased from 76,000 in 1981 to nearly 400,000 sets today. Toshiba Consumer Products has diversified its production... This year the company will produce over 1000,000 video cassette recorders... and 170,000 microwave ovens... The company is proud of its achievements but recognises that teamwork is the key to success. The co-operation that exists between English and Japanese, union and management, management and non-management and production and sales has allowed Toshiba Consumer Products to overcome the problems associated with rapid growth.

The Finance Director commented that the company had 'grown beyond our wildest dreams'. A factor in this growth has been industrial peace and the then Chairman of Toshiba in Japan, Mr. S. Saba, who attended the celebrations along with other senior managers and local dignitaries etc, made a point of emphasising that the factory at Plymouth 'had not lost a minute because of industrial action'. Mr. Saba then went on to say that, 'This is the most successful of our manufacturing operations outside Japan. Apart from our technology here, the thing I appreciate most is the diligent workforce and the good management'. Mr. Saba admitted that he had previously been 
worried about the UK's 'poor reputation for industrial relations' but said that these worries had now disappeared and that the agreement reached between the company and the union had shown that, 'the UK need not have conflict between management and unions'. On a previous visit to Plymouth shortly after the start up in May 1981, he had spoken to all the employees at the end of the working day and, doubtless to encourage them and to give them the feeling that they had a stake in the new venture, had emphasised what he saw as the organic nature of the company and the way in which management would be a local responsibility in operational matters, as in Item b of Table 1 above. He used some quite poetic imagery :

Toshiba has no intention of ruling over this company. The company is yours. It is like a small mustard-seed which you took and sowed in your garden; it grows to be a tree and the birds come to roost among its branches. The future of the company rests on your shoulders. Your efforts, and nothing else, will make the company prosperous and give your family happiness. Toshiba will support you in this endeavour, providing you with capital and technology. Do your best !

It is an unfortunate fact that in many British companies the Managing Director, not to mention the Chairman, would be unlikely to think that it was important to communicate anything about the company to the people working in it. Here again, Japanese companies have drawn renewed attention to the issue of communication, without which the best results are unlikely to be achieved.

The representative system

Communication was emphasised among the actions to develop positive employee attitudes' listed in Table 1 above but, 
like other parts of the management system, it needs to be seen in the context of the new approach as a whole.

The Company Advisory Board (COAB) is the centrepiece of the representative system although, as the Industrial Participation Association noted, it is at the same time 'one element only in a total company employment package' ${ }^{18}$. COAB originally consisted of ten representatives, elected by secret ballot from every level and department of the company, plus the senior union representative, who is automatically a member if not already elected as a departmental representative. A large round table, with no 'top', was specially made and the Managing Director is normally the chairman : something underlining the seriousness with which the company takes COAB. When the new Home Appliance (HA) Division was established in 1985 to produce microwave ovens, COAB was expanded to include its representatives, since both Divisions were under the same umbrella organisation and it was felt that a separate $\mathrm{COAB}$ would be too small and isolated.

Representatives need not be union shops stewards, although today many are, on the principle that people should be selected on their own merits and not just because they held a union position. But it was also recognised that it would be important for union shop stewards to attend any meetings where the annual pay settlement was under discussion and they have the right to do so.

To ensure that meetings are open and above board, to interest potential representatives in $\mathrm{COAB}$ and what it does and to help to diffuse information, five or six observers may attend. These are simply anyone who is interested and are not selected in any way. During the job satisfaction study carried out in 1987 it was possible to talk to employees who had attended meetings as observers and to find that even the most 
sceptical had been impressed by the openness of the discussion and convinced that the meetings were not 'fixed' in advance.

COAB can discuss, in the words of Geoffrey Deith, 'any subject from the size of the Managing Director's car to the annual salary review'. The relationship with the union is that of 'negotiation by advice' in the first instance. If $\mathrm{COAB}$ were to fail to agree on wages or conditions, then there would be ordinary straightforward bargaining between the management and the union.

There is full disclosure of company information, including financial and production-related information, to COAB; without which it would be unlikely either to have credibility with employees or be able to function effectively. Of course, merely providing information about exchange rate fluctuations or production targets, for instance, could degenerate into something mechanical unless there are efforts to explain what it means in real terms for the prospects of the company and the job security and earnings of those who work in it. So the management has put a lot of time and effort into discussing with $C O A B$ representatives what the figures mean and into explaining them to the whole of the workforce at the sixmonthly performance reviews. In addition, there are the fiveminute meetings at the beginning of work, which are really for briefing about operational matters such as production runs, targets and what problems to look out for, COAB itself meets regularly at least once a month.

It needs to be stressed that $C O A B$ is an advisory body and that ultimate responsibility for the progress of the company resides with the Board but its recommendations are taken seriously by the management. This can be verified by looking at the record of recommendations accepted, which there is unfortunately no space to go into here. Attendance at a $\mathrm{COAB}$ meeting also provided an opportunity to see how seriously it is 
taken by the elected members, who do not waste time with trivia. The senior shop steward commented that it is, 'Not all sweetness and light, but it is honest, durable, and it works'. Anything, apart from individual cases that should be taken up in the normal way in the department, can be put on the agenda by any member.

Feedback to all employees was originally provided by videotapes, which were made available for the Policy Studies Institute study and which are quoted in the book, but this was felt to lack the participatory element. One can not ask a tape questions or discuss with it. So the practice was dropped in favour of feeding back information after $C O A B$ meetings directly to employees at the regular five-minute morning meetings. This helps to ensure that the whole workforce is kept up to date with what is going on and that no one is left out.

So far, $\mathrm{COAB}$ has been able to settle all matters raised, including wage negotiations, without recourse to the final stage of the agreed procedure. If management-union negotiation, the second stage of the advisory system, were to fail then there is provision for an issue to go forward to a third and final stage. This is 'pendulum' arbitration, which both management and union have agreed is binding. 'Pendulum' arbitration means that the arbitrator, an independent person brought in from outside, must settle either wholly for one party or wholly for the other. The arbitrator is not allowed to settle in the middle between the two positions, or to 'split the difference' as 'traditional' arbitration allows for. The idea is to encourage both parties to moderate their demands, thus making it easier to reach a settlement.

It is of interest that this system is American, not Japanese, and that its provision was suggested by the National Officer of the EETPU, who had learned about it while visiting the United States. Indeed COAB itself has its roots in the Glacier Metal 
Company case and in Geoffrey Deith's previous experience in running such a body and is not usual in companies in Japan.

British industrial relations still have a 'voluntarist' base, although there is now more industrial relations legislation in force, concerning strike ballots and secondary action for example, that there was a few years ago. But there are not the legally enforceable contracts of the American system, the institutionalised arrangements of the German system of codetermination or the same role for the state and its organs that there is in many Continental countries. The expression 'no-strike agreement' is therefore a piece of convenient shorthand rather than a strictly accurate technical term. It seems unlikely that employees would be unlikely to be deterred by a piece of paper if management had allowed the situation to deteriorate to such an extent. But there is no evidence to suggest that the representative system at Toshiba, through the effectiveness of $\mathrm{COAB}$, would allow the situation to get to this point.

The importance of the suppliers

The last of the four 'key principles' guiding the start up, quoted above, was 'to develop suppliers attitudes' : something unusual in a company policy statement of this type.

The initiative was taken by Geoffrey Deith, who held the first of the suppliers' conferences at a hotel not far from London. It was attended by the representatives of 150 suppliers. Deith's purpose was to explain 'what we would expect of a supplier, what the systems would look like and the enthusiasm and maximum expected'.

All companies like Toshiba in Japan have their own associations for suppliers and sub-contractors. There are 
regular monthly meetings and continual close contact between manufacturer and supplier. The interest of both parties in longterm relations that foster mutually profitable development work is taken for granted; but in Britain, with a few exceptions, such a level of cooperation is rare. Japanese customer companies vet their new suppliers with great care before deciding whether to take them on or not and they make exacting demands on them; but they also provide technical assistance, the loan of sophisticated machines and equipment and management support. A number of employees in Japan from the medium and small enterprise sector, from which many suppliers come, can be found as trainees in the customer companies, where they naturally learn what the customer wants. Equally, if a supplier gets into difficulties, the customer company may second managers to it in order to get it back on the rails again. These concerted efforts to ensure that suppliers can produce components of the right quality, at the right price, delivered on time bring obvious competitive benefits to the customer companies. Having once decided to work with a supplier, they are anxious not to waste their investment of time, effort and prestige and will only dismiss a supplier if it finally shows that it is unable to improve in spite of being both helped and warned. It is a system that benefits both customers and suppliers, since it helps all of them to become more competitive, particularly by making the type of cost savings that can only be produced in the long run : never in the short run. What incentive does a supplier have to invest unless he can be reasonably confident of a stable relationship with the customer?

For Toshiba at Plymouth, it was clear that the reliable supply of components of consistent quality and suitable price was an essential link in the chain of the TV production system; and that relations with suppliers for a new company whose object was to integrate and upgrade its operations could have a decided effect on performance. There would, after all, be little point in putting a great deal of effort into ensuring that the 
workforce was well informed, well motivated and well trained if production were to be halted by shortages of components; and warehousing to keep components 'just in case' suppliers' deliveries were unreliable would be a waste of money in any case. A year after its start up therefore TCP began its policy of visits by suppliers' employees to the Plymouth factory, so that they could learn at first hand from TCP operators what the requirements were and what problems would be caused by late or incorrect deliveries : something unheard of in 'traditional' British companies. Suppliers were also invited to the celebration of the millionth TV and one, who has 90 per cent of his business with Japanese firms, travelled over from Ireland.

Initially, TCP suffered shortages in the numbers of components delivered by local suppliers. It felt the problem was serious enough to involve the entire personnel of the factory, from the Finance Director (!) to shop floor operators in physically counting one and a half million components. As Des Thomson pointed out, counting is something that everyone can do and it made everyone aware of the problem and that its solution was crucial to the success of the enterprise as a whole : it was not 'just a procurement matter'. This commitment has gradually paid off and there has been the gradual change in suppliers' attitudes and performance that was aimed at.

From the Japanese point of view, the two major problems involved in manufacturing in Europe are employee or industrial relations and finding good local suppliers who are willing and able to provide the level of service that they require. The former is not perhaps surprising but the latter has received far less attention; even though it has been consistently referred to in the annual reports on the state of Japanese manufacturing in Europe, now produced in English by the Japan External Trade Organisation (JETRO). Such reports give an important insight into the priorities of Japanese manufacturers ${ }^{9}$. 


\section{Toshiba as a model ?}

Between 1981 and 1987 the company grew to nearly four times its original size. The proportion of products coming off the line 'right first time' rose from 60 per cent to 93 per cent. Output per person increased from 93 to 250 . New products video tape recorders and microwave ovens - and a new Division were added to the operation. There was substantial growth in sales and market share (the exact figures were made available for the study but can not be reproduced because of business confidentiality) and no time was lost because of industrial disputes. These data indicate the success of the new approach and, in addition, a number of Japanese and other companies in the UK have established employee relations systems that follow the Toshiba example. Hitachi, for instance, has a 'company members' board', Sanyo has 'pendulum' arbitration and, in an industry that since the war has experienced considerably more difficulty than consumer electronics, Nissan has introduced a 'package' of measures aimed at the same type of integrated approach as Toshiba's ${ }^{10}$.

The problems at Toshiba - and managers are modest in insisting that what they have is not a panacea or some kind of 'patent medicine' guaranteed to cure all ills - are those connected with this type of industry and with growth and success. Assembling TV sets, VTRs or microwave ovens inevitably involves repetitive work that has limited intrinsic interest and a challenge for all managements in this field is how to introduce measures, such as job rotation and small circle activities, to make it more interesting. The pressure to produce to keep up with the demands of a very competitive market likewise causes stress and again it is a challenge for management to see that the human side of managing a company gets enough attention when time is short. Growth has also meant a change from a relatively small, close-knit organisation, in which there was a camaraderie brought about 
by the trauma of the collapse of the old company, to a larger organisation, in which the longer-serving and somewhat older members of the firm are outnumbered by newer, younger employees, who tend to take the improvements and innovations, such as 'single status', for granted. The full-length book on TCP gives the findings from the 1987 interviews and job satisfaction survey.

TCP may not be Utopia, and none of its managers would claim that it was, but it is a vast improvement on 'traditional' British companies : a fact particularly appreciated by the older employees with the actual experience of having worked in one. Equally, every company's situation and personnel are different, and there is no slick formula that can apply to large companies, small companies, manufacturing companies, sales and distribution companies, financial institutions etc. But it is nevertheless possible to point to certain features of the Toshiba experience that managers of other companies facing the same type of problems that TCP faced initially could profitably study.

It would of course be possible to make a long list of all the factors underlying the successful implementation of the new approach but four, mutually supportive, factors stand out. They are :

1. Vision (where does the company want to go and how will it get there?)

2. Leadership (active and forward-looking, not bureaucratic)

3. Pragmatism (the method by which TCP arrived at its new approach, aimed at achieving its objectives) 
4. The right people (careful selection of the management team, who would actively support the new approach : building an organisation of employees of the right type, who would be motivated towards high quality performance).

If any one of these factors is lacking, the attempt to innovate will be flawed, because it will not be properly integrated.

\section{Analysis}

Any of the practices successfully used by Japanese companies and of their implications for British companies, carried out by the heads of training and personnel respectively in companies belonging to an international group, did not recommand an unthinking imitation of Japanese practices but it did identify five significant areas into which British companies could put an effort if they wanted to get the kind of employee response' that had been of such great benefit to Japanese companies ${ }^{11}$. The areas were :

1. Security of employment (TCP's 'established members', after a probationary period and two years service)

2. Common employment conditions ('single status')

3. Training (flexibility, grading scheme)

4. Communication and employee involvement (meetings, $\mathrm{COAB}$ )

5. 'Local focus' of industrial relations (COAB, 'single-union' agreement, 'pendulum arbitration).

To a greater or lesser extent, all five areas feature in the management systems of TCP and other manufacturers in 
Britain. The TCP case and others like it show that when the company structure, the production system and arrangements with suppliers etc. are no longer able to respond to current needs, then piecemeal attempts to patch up the system will not work. A new approach, involving employee relations, the different aspects of production and marketing that were outlined above and supplier relations is needed - and it must be integrated and thoroughgoing 'from day one'.

That is probably the most important conclusion for managers and policy makers to draw from Toshiba's experience at Plymouth. 


\section{NOTES}

1. For the full account of the Toshiba case, see: Trevor, M.H. Toshiba's new British Company. Competitiveness through Innovation in Industry. Policy Studies Institute, London. 1988.

For case studies of Japanese joint ventures and collaborative agreements in the UK, see : Trevor, M.H. Japanese Industrial Knowledge. Can it help British Industry? Gower, Aldershot. 1985/

2. For Japanese and European views of these systems, see : Trevor, M.H. and Holl, U. (eds). Just in Time Systems and Euro-lapanese Industrial Collaboration. Campus Verlag, Frankfrut. 1988. This includes an explanation by the Materials Director of Toshiba Consumer Products (UK) of 'Toshiba's Approach to Purchasing' and an account by a European company of how it has implemented its new integrated approach to marketing and production.

3. A comparison of manufacturer-supplier relations in Britain and Japan and of what Japanese manufacturers expect from their suppliers is given in : Trevor, M.H. and Christie, I.P. Manufacturers and Suppliers in Britain and Japan. Competitiveness and the Growth of Small Firms . Policy Studies Institute, London, 1988.

4. Cf . Brown, W. Exploration in Management. A Description of the Glacier Metal Company's Concepts and Methods of Organisation and Management. Heinemann, London, Penguin, Harmondsworth. 1960.

5. De Jonquieres, G. and Lloyd, J. 'Toshiba takes on a salvage mission'. Financial Times, London, 3 April 1981.

6. Komada, K. 'Productivity and Self Motivation of the British Workforce in a Japanese Firm'. Japan in Britain, TTI (UK) Ltd. and Inbucon Management Centre Ltd., London. 21 January 1982.

7. Bassett, P. Strike Free : New Industrial Relations in Britain . Papermac, Macmillan, London. Revised edition 1987.

8. 'Toshiba in the UK. How a Japanese company set out to involve and motivate its UK workforce', Industrial Participation. Industrial Participation Association, London. Winter 1981-2. 
9. Japan External Trade Organisation. Japanese Manufacturing Companies operating in Europe. (third Survey Report). JETRO, Tokyo, 1987.

10. Leese, J. 'The Nissan agreement - a work philosophy', Employment Gazette. Department of Employment, London. August 1985.

11. Brown, G.F. and Read, A.R. 'Personnel and training policies - some lessons for Western companies'. Long Range Planning . Vol. 17. $\mathrm{n}^{\circ}$ 2., Pergamon, Oxford. 1984. 


\section{RESUME}

Le chiffre d'affaires de Toshiba Consumer Products (UK) Ltd a quadruplé de 1981 à 1987. La productivité a sensiblement augmenté et la gamme des produits a été élargie. La gestion de TCP n'est sûrement pas parfaite mais elle montre une nette amélioration par rapport à celle adoptée par les firmes britanniques traditionnelles. Il est très difficile de généraliser et aucune formule ne peut s'appliquer indifféremment à de grandes entreprises, à des petites, à des fabricants ou à des firmes de distribution. Cependant, il est possible de tirer de l'expérience de Toshiba des enseignements profitables aux managers d'autres entreprises ayant à faire face aux mêmes problèmes.

Il ne s'est pas agi de l'imitation indiscriminée de méthodes japonaises mais de l'identification de points sur lesquels les managers européens devraient réfléchir pour obtenir du personnel, la motivation qui a tant profité aux entreprises japonaises. 